\title{
PENGARUH PENERAPAN SISTEM ENTERPRISE RESOURCE PLANNING (ERP) DAN KUALITAS SISTEM INFORMASI AKUNTANSI TERHADAP EFEKTIVITAS PENGENDALIAN INTERNAL ATAS PELAPORAN KEUANGAN PADA PT WASKITA KARYA TBK (STUDI EMPIRIS UNIT KERJA YANG BERADA DI BAWAH KANTOR DIVISI I INFRASTRUKTUR)
}

\author{
Muhammad Farradhi ${ }^{1}$, Evayani ${ }^{* 2}$ \\ ${ }^{1,2}$ Program Studi Akuntansi Fakultas Ekonomi Universitas Syiah Kuala \\ e-mail: m.farradhi@gmail.com, evayani@unsyiah.ac.id ${ }^{* 2}$ \\ * Corresponding Author
}

\begin{abstract}
This paper is intended to determine the application of Enterprise Resource Planning (ERP) applications and the quality of accounting information systems towards the implementation of internal control over financial reporting at PT. Waskita Tbk. The population in this study was PT Waskita Tbk employees who were under the Division I office in charge of the Sumatran region with a total population of 552 employees, with a sample used by 100 employees. Data analysis method in this study uses multiple regression analysis. The results showed that the simultaneous Corporate Resource Planning System and the quality of the accounting information system influence significant effect for the assistance of internal control over financial statements. While Enterprise System Resource Planning has a significant effect on internal control over financial reporting, accounting accounting information systems have a significant effect on controlling financial reporting. Researching to improve internal control over reporting, PT. Waskita Tbk. Continue to renew the use of information technology to be able to increase the use of internal control.
\end{abstract}

Keywords: Enterprise System Resource Planning, Quality of Accounting Information Systems and Internal Control Effectiveness

\section{Pendahuluan}

Pengendalian Internal adalah suatu turunan dari teknologi informasi yang diciptakan dalam bentuk sistem, dalam prakteknya pengendalian internal dijalankan oleh petinggi perusahaan dan juga segala jabatan yang ada pada perusahaan yang akan berdampak langsung atau tidak langsung di perusahaan. Sebuah Sistem Informasi berusaha untuk menggabungkan seluruh proses bisnis pada perusahaan, baik yang berasal dari departemendepartemen dan unit bisnis yang berbeda pada suatu perusahaan, penggunaan metode Single Data Entry adalah teknik yang dianggap tepat untuk penyeragaman data. Sistem Enterprise Resource Planning (ERP) merupakan sebuah software yang digunakan oleh perusahaan untuk memperbaiki good corporate governance (Catalya \& Hadiprajitno, 2014)

Pemeriksaan yang dilakukan BPK (Badan Pemeriksa Keuangan) bentujuan khusus atau pemeriksaan dengan tujuan tertentu (PDTT) dengan objek pemeriksaan 21 BUMN, pemeriksaan dilakukan untuk memeriksa aktivitas operasional perusahaan. Pemeriksaan dilakukan untuk mengetahui apa yang menjadi penyebab lenyapnya kapasitas pendapatan perusahaan BUMN. Berdasarkan rangkuman hasil dari pemeriksaan pada semester II tahun 2015, melibatkan 21 objek yang diperiksa mengenai aktivitas operasional perusahaan BUMN dan 3 objek meliputi pemeriksaan lahan perkebunan dan pertanian yang dimiliki oleh perusahaan BUMN. BPK juga memeriksa pengelolaan aktivitas operasional 21 perusahaan BUMN, yang melibatkan 18 Persero dan 3 Perum. Badan Pemeriksa Keuangan menegaskan bahwa terdapat 264 temuan yang mengungkapkan ada 348 permasalahan. berdasarkan pemeriksaan yang dilakukan, BPK mengungkapkan bahwa ada 164 temuan pada kelemahan Sistem Pengendalian Internal (SPI) dan 184 temuan karena ketidakpatuhan 
perusahaan pada Peraturan Perundang-Undangan. Temuan kelemahan Sistem Pengendalian Interal terjadi ketika BUMN telah merancang dan menyusun Sistem Pengendalian Internal dengan bagus dan siap untuk dilaksanakan oleh seluruh karyawan dan pimpinan perusahaan, namun dalam penerapannya belum optimal sehingga menimbulkan masihnya banyaknya terjadi penyimpangan (www.bpk.go.id)

Publikasi berita yang dimuat oleh Kompas.com pada 18 Desember 2018, mengungkapkan bahwa Ketua Komisi Pemberantasan Korupsi (KPK) Agus Rahardjo memberikan peringatan kepada BUMN (Badan Usaha Milik Negara) harus memperketat penerapan prinsip tata kelola perusahaa yang baik, hal itu berkaca pada telah ditetapkannya 2 pegawai PT. Waskita Karya Tbk sebagai tersangka terkait dengan modus-modus korupsi anggaran proyek kontruksi, kedua pegawai PT. Waskita Karya Tbk tersebut diduga telah bekerjasama dengan perusahaan subkontraktor untuk membuat beberapa proyek yang diangap ada namun sebenarnya proyek tersebut fiktif atau tidak ada yang mana proyek tersebut di ciptakan oleh kedua pegawai tersebut untuk tujuan tertentu. KPK menduga ada 4 perusahaan subkontraktor mendapatkan tugas dari PT. Waskita Karya Tbk untuk mengerjakan 14 proyek yang diidentifikasi sebagai proyek fiktif.

Menurut KPK, PT. Waskita Karya Tbk sudah membayar sejumlah uang kepada perusahaan rekanan subkontraktor, setelah itu perusahaan rekanan subkontraktor mengembalikan kembali sejumlah uang pembayaran dari PT.Waskita Karya Tbk tersebut kepada kedua tersangka dan uang tersebut digunakan untuk keperluan pribadi dari kedua tersangka (Kompas.com).

Menurut Garside (2004) masih banyak Software Enterprise Resource Planning gagal pada penerapan sistem tersebut. Gagalnya penerapan sistem ERP terjadi rata-rata pada tahapan implementasi. Kegagalan yang terjadi pada implementasi software ERP berdasarkan hasil survey adalah mencapai angka 50 persen sampai dengan 70 persen angka tersebut menunjukan betapa besarnya kegagalan dalam penerapan software ERP. Beberapa penelitian yang menyatakan tingkat kegagalan sebesar 70 persen merupakan ketetapan yang dapat dimaklumi secara umum pada proyek Teknologi Informasi (TI) yang dikerjakan. Selanjutnya Standish Group merupakan perusahaan penasehat yang melakukan penelitian terhadap Teknologi Informasi (TI) mengunkapkan tinggat keberhasilan penerapan sistem ERP hanya 10 persen dari seluruh perusahaan yang telah mencoba menerapkan sistem ERP, proyek penerapan sistem ERP yang dibatalkan sebanyak 35 persen serta yang mengalami keterlambatan pada penerapan dan implementasi sistem ERP sebanyak 55 persen.

\section{Kerangka Teoritis Dan Pengembangan Hipotesis \\ Sistem Enterprise Resource Plannings}

Menurut Susanto (2014:20), menjelaskan "Enterprise Resource Planning (ERP) merupakan software paket terintegrasi yang dirancang khusus untuk memberikan integrasi yang menyeluruh terkait dengan Sistem Informasi perusahaan." Software ERP sebagai sistem yang penggunaannya melalui media elektronik baik kumputer, gadget dan sebagainya yang dapat terhubung dengan koneksi internet. Cakupan sistem informasi dapat memudahkan manajemen dari perusahaan untuk memperoleh informasi yang diperlukan oleh perusahaan untuk memastikan kelangsungan dari operasi perusahaan. Sistem ERP memiliki fungsi yang fatal bagi perusahaan karena sistem ERP dapat memastikan suatu tujuan pengendalian internal berjalan sesuai yang diharapkan. Yaitu pengendalian pada akuntansi untuk memastikan pelaporan keuangan yang dihasilkan reliable. Dasarnya secara standar, software ERP umumnya dibagi atas standar utama yakni Operasi serta standar pembantu yakni Finansial dan Akuntansi serta Sumber Daya Manusia. Standar Finansial dan Akuntansi sebagai standar yang bertanggung jawab ats fungsi manajemen keuangan dan mendukung analisis dari berbagai aktivitas bisnis dengan lokasi yang berbeda untuk dapat dijadikan sebagai satuan yang saling terhubung terdiri dari subsistem-subsistem sebagai berikut:

1. Akuntansi finansial (buku besar, akun piutang dan utang, aset tetap, konsolidasi)

2. Pengendalian (biaya overhead, biaya dasar aktivitas, biaya produk, analisa laba)

3. Manajemen investasi (perencanaan, penganggaran, pengawasan)

4. Treasury

5. Enterprise Controlling (manajemen sistem informasi, perencanaan bisnis dan 
penganggaran, profit center cost) (Catalya \& Hadiprajitno 2014).

\section{Gambar Konsep Enterprise Resource Planning System}

KONSEP DASAR ERP
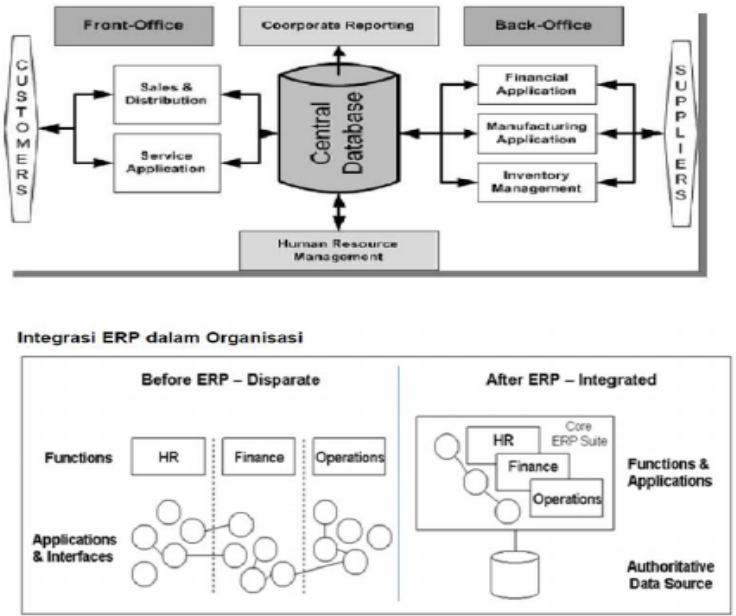

Sumber :Hari Y. Poernomo, E-business: Enterprise Resource Planning

\section{Kualitas Sistem Informasi Akuntansi}

Menurut Mc. Leod dalam buku Azhar Susanto (2014:40) menjelaskan tentang Kualitas Informasi sebagai adalah Informasi dikatakan berkualitas apabila memiliki ciri-ciri yaitu seperti: akurat, relevan, tepat waktu, dan lengkap. Kualitas Sistem Informasi Akutansi merupakan integrasi dari semua unit bisnis dan subunit bisnis yang terkait yang ada pada perusahaan. Membentuk Sistem Informasi Akuntansi yang bisa menghasikan informasi berkualitas. Unitunit tersebut sering dianggap sebagai unsur dari Sistem Informasi Akuntansi terdiri dari prosedur, software, database, hardware, dan koneksi internat, dan mudah untuk diakses dimanaja saja. Setiap sistem akan dapat saling berhubungan satu sama lain dan juga beroperasi secara bersama untuk mengelola data dan informasi transaksi yang terkait dengan keuangan serta menghasilkan sebuah informasi keuanan yang dapat menjadi bahan pertimbangan bagi petinggi perusahaan dalam mendukung pengambilan keputusan (Syaifullah, 2010)

Sebuah konsep dasar Sistem Informasi Akuntansi yang terdiri dari semua elemen-elemen yang saling berkaitan agar dapat membentuk sebuah Sistem Informasi Akuntansi yang menghasilkan data dan informasi yang memiliki kualitas mumpuni.
Menurut Istianingsih (2009) terdapat beberapa tahapan untuk dapat menghasilakn sebuah data dan informasi yang berkualitas dari sebuah Sistem Informasi Akuntansi, sebagai berikut:

1. Kualitas pelayanan

2. Kualitas sistem

3. Kualitas informasi

\section{Efektivitas Pengendalian Internal}

Sesuatu dimiliki dan dikendalikan dewan direksi, manajemen dan karyawan dari sebuah perusahaan yang merupakan bagian integral dari sistem informasi akuntansi disebut sebagai Internal Control. Menurut Herawati (2014) Sebuah aturan dan prosedur yang diciptakan untuk memberikan kebutuhan mencukupi bagi manajemen dan memastikan organisasi berjalan ataupun bekerja sesuai dengan tujuan yang seharusnya disebut sistem Pengendalian Internal. Pegembangan unsur dari untuk meningkatan Sistem Pengendalian Internal harus mempertimbangkan aspek sumber daya manusia, jelas atau tidaknya pengukuran efektivitas, biaya manfaat dan perkembangan dari Teknologi Informasi yang semua item tersebut dilakukan secara komprehensif (Rahmawati, 2018).

Menurut Wakhyudi (2018:2) pengendalian internal termasuk didalamnya unsur pimpinan dan anggota dalam suatu organisasi yang sangat mempengaruhi keamanan aset, kepatuhan terhadap peraturan, akurasi pelaporan dan berjalannya operasi organisasi secara efisien dan efektif. Pengendalian Internal dibutuhkan untuk kepentingan organisasi dalam pencapaian tujuan organisasi. Terdapat dua unsur penting dalam Pengendalian Internal yaitu keberadaannya dan berfungsinya Pengendalian Internal. Kondisi yang memberikan gambaran tentang pelaksanaan Pengendalian Internal ada tiga. Kondisi pertama, pengendaliannya telah ada namun dalam pelaksanaannya tidak ada pelaksanaan Pengendalian Internal yang dilakukan. Kondisi kedua, pengendalianya telah ada dan dalam pelaksanaannya hanya berjalan sebagian dari keseluruhan dari seharusnya pelaksanaan Pengendalian Internal tersebut. Kondisi ketiga, pengendaliannya telah ada dan seluruh tahapan telah dilaksanakan.

Menurut Harahap (2015) komponen pengendalian internal COSO (The Committee Of Sponsoring Organizaton) meliputi : 
1. Lingkungan pengendalian

2. Aktivitas pengendalian

3. Penafsirann resiko

4. Informasi dan komunikasi

5. Pengawasan

\section{Metode Penelitian}

Penelitian ini merupakan penelitian survei dengan menggunakan kuesioner sebagai alat mengumpulkan data, mendesain studi, menyiapkan intrumen survei yang reliable dan valid, mengelola survei, menganalisa data survei dan menlaporkan hasil yang diperoleh selama penelitian. Unit analisis pada penelitian ini Pegawai unit kerja PT. Waskita Karya Tbk yang berada pada Kantor Divisi I Ifranstruktur wilayah sumatera.Populasi pada penelitian ini pegawai yang bekerja pada pada bagian Administrasi dan Kontrak, Keuangan, Logistik, Pelaksana, Pengendalian Mutu, Sumber Daya Manusia dan Teknik. Pemilihan responden yang akan dipilih secara acak berdasarkan kesediaan responden untuk mengisi kuesioner penelitian yang dilakukan pada unit kerja pada wilayah Kantor Divisi I Ifranstruktur yang mengelola pada wilayah Sumatera dengan jumlah 552 orang. Pemilihan sampel bedasarkan simple random sampling dengan Rumus Slouvin pada penggunaan error sebesar 9\% diperoleh sampel pada penelitian ini sebanyak 100 orang pegawai. Data dari penelitian akan diolah menggunakan uji regresi berganda

Penelitian ini menggunakan data sekunder sebagai bagian dari mengumpulan informasi dari sumber-sumber yang telah ada dan peneliti menggunakan data primer dengan pendekatan penggunaan kuesioner sebagai alat akan diberikan melalui elektronik dengan media google form yang akan disebarluaskan melalui perantara Aplikasi WhatsApp. Pengukuran pada kuesioner penelitian menggunakan point skor, dimulai dengan angka 1 sebagai sangat tidak setuju, 2 sebagai tidak setuju, 3 sebagai netral, 4 sebagai setuju, 5 sebagai sangat setuju, yang akan diberikan atau dikirimkan kepada target atau objek penelitian ini iyalah pegawai PT. Waskita Karya Tbk wilayah sumatera.

Menurut Romney \& Steinbart (2015:29) terdapat beberapa indikator terkait dengan Sistem Enterprise Resource Planning (ERP) yaitu : 1) Paket perangkat lunak. 2) Integrasi seluruh operasi. 3) Transaksi keuangan. 4) Penyimpanan data. 5) Real time. 6) Perencanaan. 7) Akurasi. 8) Sistem multi mata uang. 9) Penyesuaian.

Kualitas Sistem Informasi Akuntansi merupakan salah satu produk informasi yang berkarakteristik atau berkualitas yang membuat informasi tersebut sangat penting bagi para penggunanya. Pengukuran variabel ini didasarkan atas beberapa indikator sebagai berikut: 1) Informasi keuangan. 2) Akurasi. 3) Netralitas. 4) Kejujuran. 5) Feedback. 6) Consensus. 7) Resiko ketidakpastian. 8) Perbandingan Kinerja. 9) Waktu penyediaan (Indrayani \& Maulidahniar, 2017).

Memperjelas dan meningkatkan fungsi organisasi dan dapat mendorong tingkat kepatuhan akan prosedur dan kebijakan yang ditetapkan oleh sistem. Penelitian ini menggunakan indikator sebagai berikut: 1) Sistem Pengendalian. 2) Tingkat otorisasi. 3) Pemisahan tugas. 4) Efektivitas pelaksanaan. 5) Hubungan seluruh aliran data. 6) Pengamanan. 7) Metode entry data. 8) Penyimpanan. 9) Input data (Indrayani \& Maulidahniar, 2017).

\section{Hasil Dan Pembahasan}

Pada penelitian ini adalah pegawai PT. Waskita Karya Tbk berdasarkan wilayah kerja yang telah ditentukan. Populasi pada penelitian ini merupakan pegawai PT. Waskita Karya Tbk di Divisi I Infrastruktur wilayah Sumatera yang berjumlah 552 orang dan sampel penelitian sebanyak 100 orang yang ditentukan menggunakan rumus slouvin dengan berdasarkan kesediaan responden dalam mengisi kuesioner penelitan. Pada bagian ini akan dijelaskan mengenai identitas responden berdasarkan Jenis kelamin, Pendidikan, Jabatan, dan Lama penggunaan.

Identitas Responden Berdasarkan Jenis Kelamin

\begin{tabular}{|cccc|}
\hline \multirow{2}{*}{ No. } & \multirow{2}{*}{ Jenis Kelamin } & \multicolumn{2}{c|}{ Jawaban Responden } \\
Frekuensi & Persen \\
\hline 1. & Laki-laki & 98 & 98,0 \\
2. & Perempuan & 2 & 2,0 \\
& Total & 100 & 100,0 \\
\hline
\end{tabular}

\section{Identitas Responden Berdasarkan Pendidikan}

\begin{tabular}{|clcc|}
\hline No. & \multicolumn{1}{c}{ Pendidikan } & \multicolumn{2}{c|}{ Jawaban Responden } \\
Frekuensi & Persen \\
\hline 1. & SMA/SLTA & 2 & 2,0 \\
2. & D1/D2/D3 & 26 & 26,0 \\
3. & S1/S2/S3 & 72 & 72,0 \\
& Total & 100 & 100,0 \\
\hline
\end{tabular}


Identitas Responden Berdasarkan Jabatan/bagian

\begin{tabular}{|clcc|}
\hline \multirow{2}{*}{ No. } & Jabatan/Bagian & Jawaban Responden \\
Frekuensi & Persen \\
\hline 1. & Administrasi dan & 15 & 15,0 \\
& Kontrak & & \\
2. & Keuangan & 14 & 14,0 \\
3. & Logistik & 18 & 18,0 \\
4. & Pelaksana & 18 & 18,0 \\
5. & Pengendalian Mutu & 4 & 4,0 \\
6. & Sumber Daya & 13 & 13,0 \\
& Manusia & & \\
7. & Teknik & 18 & 18,0 \\
& $\quad$ Total & 100 & 100,0 \\
\hline
\end{tabular}

Identitas Responden Berdasarkan Lama Penggunaan

\begin{tabular}{|cccc|}
\hline \multirow{2}{*}{ No. } & Lama Penggunaan & $\begin{array}{c}\text { Jawaban Responden } \\
\text { Frekuensi }\end{array}$ & Persen \\
\hline 1. & 1-3 Tahun & 10 & 10,0 \\
2. & 3-5 Tahun & 25 & 25,0 \\
3. & > T Tahun & 64 & 64,0 \\
& Total & 100 & 100,0 \\
\hline
\end{tabular}

\section{Uji Validitas}

Pengujian validitas data dalam penelitain ini dilakukan secara statistik, yaitu dengan mengunakan uji Pearson Product-Moment Coeffisient of Corelation menggunakan bantuan software computer melalui program Statistic Package for Social Science (SPSS) 25. Berdasarkan hasil pengolahan data seluruh pernyataan valid karena memiliki nilai signifikansi dibawah $5 \%$.

\section{Uji Reliabilitas}

Menguji kehandalan kuesioner yang digunakan, penelitian ini menggunakan uji reliabilitas. Analisa digunakan untuk menafsirkan kolerasi antara skala yang dibuat dengan skala variabel yang ada. Hasil uji reliabilitas pada tabel 4.6 menjelaskan variabel dependen dan variabel independen menunjukkan hasil yang reliabel. Nilai cronbach alpha yang dihasilkan > 0.60 sehingga seluruh variabel yang digunakan dinyatakan handal.

Hasil pengolahan data memperlihatkan nilai cronbach alpha untuk masing-masing variabel yakni sebesar 0,859 untuk variabel Sistem ERP, sebesar 0,936 untuk variabel kualitas SIA, dan sebesar 0,784 untuk variabel efektivitas pengendalian internal.

\section{Uji Normalitas}

\begin{tabular}{|llr|}
\hline & & $\begin{array}{c}\text { Unstandardized } \\
\text { Residual }\end{array}$ \\
\hline$N$ & & 100 \\
Normal Parameters & a,b & Mean \\
& Std. Deviation & .0000000 \\
Most Extreme & Absolute & .16327059 \\
Differences & Positive & .084 \\
& Negative & .084 \\
Kolmogorov-Smirnov Z $Z$ & -.061 \\
Asymp. Sig. (2-tailed) & .838 \\
\end{tabular}

Berdasarkan Tabel 4.7 diperoleh nilai Asymp. Sig. (2-tailed) sebesar 0.483. Nilai signifikan $>0.05$ yang artinya data berdistribusi secara normal.

\section{Uji Multikolinearitas}

\begin{tabular}{|lccl|}
\hline $\begin{array}{c}\text { Variabel } \\
\text { Bebas }\end{array}$ & Tolerance & VIF & \multicolumn{1}{c|}{ Keterangan } \\
\hline $\begin{array}{l}\text { Sistem ERP } \\
\begin{array}{l}\text { Kualitas } \\
\text { SIA }\end{array}\end{array}$ & 0,819 & 1,221 & $\begin{array}{l}\text { Bebas dari } \\
\text { Multikolinieritas }\end{array}$ \\
\hline
\end{tabular}

\section{Uji Heteroskedastisitas}

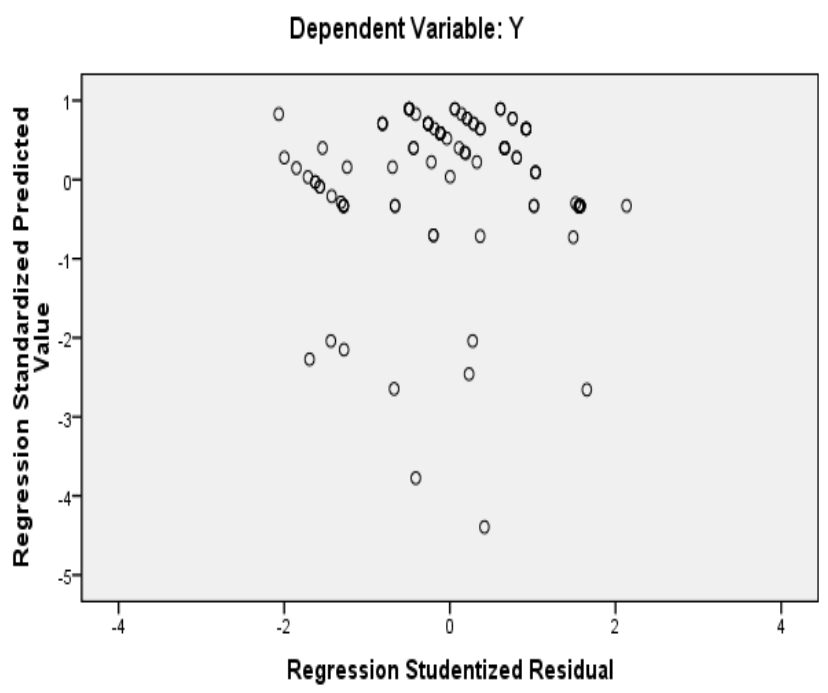

\section{Koefisien Korelasi (R)}

Koefisien korelasi $\mathrm{R}$ sebesar 0,773 menjelaskan derajat hubungan (korelasi) antara variabel Sistem ERP (X1) dan kualitas SIA (X2) dengan efektivitas pengendalian internal (Y) adalah positif dengan keeratan hubungan 77,3\%. Artinya kedua variabel bebas tersebut memiliki hubungan yang kuat dengan 
efektivitas pengendalian internal (Y) dengan nilai kategori 60\%-80\% pada tabel interval koefisien.

\section{Koefisien Determinasi ( $R$ square)}

Koefisien determinasi merupakan koefisien yang menjelaskan besarnay pengaruh dari salah satu variabel bebeas terhadap variabel tidak bebas dengan anggapan variabel-variabel lain tidak diketahui. Hasil output SPSS di peroleh Adjusted $R$ Square adalah sebesar 0,597. Nilai Adjusted $R$ Square sebesar tersebut menjelaskan, pengaruh variabel Sistem ERP (X1) dan kualitas SIA (X2) dalam mempengaruhi efektivitas pengendalian internal (Y) adalah sebesar 0,559 atau 59,9\%. Sementara sisa (nilai residu) dari peran variabel tersebut adalah sebesar 0,401 atau $40,1 \%$ dipengaruhi oleh variabel lainnya yang tidak dilibatkan dalam penelitian ini.

\section{Uji Signifikansi Bersama-sama (Uji Statistik F)}

Uji F dilakukan untuk melihat pengaruh variabel independen terhadap variabel dependen secara bersama-sama (secara simultan). Bila F-hitung >Ftabel dengan tingkat signifikan 5\% maka dapat disimpulkan bahwa secara bersama-sama variabel independen berpengaruh signifikan terhadap variabel dependen. Sebaliknya jika F-hitung < F-tabel tingkat signifikan 5\% maka dapat disimpulkan variabel independen tidak berpengaruh terhadap variabel dependen.

Berdasarkan hasil perhitungan diperoleh nilai Fhitung sebesar 71,977 dengan batasan nilai probabilitas signifikansi adalah 0,000 . Sementara nilai F-tabel pada taraf signifikan 5\% dan df 97 adalah sebesar 3,09. Dengan demikian nilai F-hitung $(71,977)$ lebih besar dari F-tabel $(3,09)$ sehingga dapat diambil suatu keputusan yaitu menerima hipotesis alternatif (Ha) dan menolak hipotesis Ho, artinya Sistem ERP (X1) dan kualitas SIA (X2) secara bersama-sama berpengaruh terhadap efektivitas pengendalian internal (Y).

\section{Uji Signifikansi Parsial (Uji Statistik t)}

Uji ini dilakukan untuk melihat signifikan dari pengaruh Sistem ERP dan kualitas SIA sebagai variabel independen secara individu terhadap efektivitan pengendalian internal sebagai variabel dependen (secara parsial). dimana dapat diketahui besarnya t-hitung untuk setiap variabel dengan tingkat signifikansi sebesar $\alpha=5 \%$. Pada dasarnya uji statistik bertujuan untuk mengetahui seberapa besar pengaruh satu variabel $\mathrm{X}$ secara parsial terhadap variabel $\mathrm{Y}$ sebagai berikut:

Berdasarkan Hasil perhitung diperoleh nilai thitung untuk pengaruh variabel Sistem ERP adalah sebesar 6,690 pada batasan nilai probabilitas signifikansi 0,000. Sementara nilai t-tabel pada df 98 dan tingkat signifikan 5\% adalah sebesar 1,9844. Hasil perhitungan ini menunjukan bahwa nilai t-hitung > nilai t-tabel sehingga dapat diambil suatu keputusan bahwa hipotesis alternatif (Ha) dapat diterima dan menolak hipotesis nol (Ho), artinya penerapan Sistem ERP (X1) dapat membantu PT. Waskita Karya Tbk untuk meningkatkan efektivitas pengendalian internal (Y) pada pelaporan keuangan dengan didukung oleh faktor lainnya. Hasil perhitungan tersebut juga memberikan gambaran kecenderungan bahwa penerapan Sistem ERP PT. Waskita Karya Tbk menunjukan bahwa dapat meningkatkan efektivitas pengendalian internal perusahaan.

Berdasarkan hasil perhitungan dengan diperoleh nilai t hitung untuk pengaruh variabel Kualitas SIA adalah sebesar 6,166 pada batasan nilai probabilitas signifikansi 0,000 . Sementara nilai t-tabel pada df 98 dan tingkat signifikan 5\% adalah sebesar 1,9844. Hasil perhitungan ini menunjukan bahwa nilai t-hitung > nilai t-tabel sehingga dapat diambil suatu keputusan bahwa hipotesis alternatif (Ha) dapat diterima dan menolak hipotesis nol (Ho), artinya kualitas SIA (X2) yang digunakan oleh PT. Waskita Karya Tbk sangat mempengaruhi secara signifikan terhadap efektivitas pengendalian internal $(\mathrm{Y})$ pada pelaporan keuangan. Yang memberikan gambaran bahwa semakin bagus Kualitas SIA yang digunakan oleh PT. Waskita Karya Tbk maka semakin bagus pula pengendalian internal pada pelaporan keuangan perusahaan.

\section{Kesimpulan, Keterbatasan Dan Saran}

Penelitian ini bertujuan untuk mengetahui pengaruh penerapan Sistem ERP, kualitas SIA terhadap efektivitas pengendalian internal. Berdasarkan hasil penelitian diperoleh kesimpulan. Sistem ERP dan kualitas SIA secara simultan atau bersama-sama berpengaruh positif terhadap efektivitas pengendalian internal pada PT. Waskita Karya Tbk. Sistem ERP secara parsial berpengaruh positif terhadap efektivitas pengendalian internal pada PT. 
Waskita Karya Tbk. Kualitas SIA secara parsial berpengaruh positif terhadap efektivitas pengendalian internal pada PT. Waskita Karya Tbk. Peneliti meyadari banyaknya kekurangan maka Peneliti menyarankan untuk mingkatkan jumlah sampel penelitian dan memperluas area penelitian atau dengan membandingkan antara perusahaan yang bergerak pada bidang industi yang sejenis, sehingga menemukan hasil yang lebih akurat dan Bagi peneliti selanjutnya, semoga penelitian ini dijadikan sebagai referensi untuk penelitian selanjutnya, namun untuk memperkuat hasil penelitian sebaiknya menggunakan pendekatan seperti kinerja pegawai, kualitas laporan keuangan dan lain-lain yang dapat ditambahkan pada penelitian.

\section{Daftar Pustaka}

Andrianto, E., \& Rahmawati, D. (2018). Pengaruh Kapasitas Sumber Daya Manusia, Pemanfaatan Teknologi Informasi, dan Sistem Pengendalian Intern Pemerintah Terhadap Kualitas Laporan Keuangan Pemerintah Daerah Dengan Komitmen Organisasi Sebagai Variabel Moderasi (Studi Empiris Pada Satuan Kerja Perangkat Daerah di Kabupaten Sleman). Jurnal Profita: Kajian Ilmu Akuntansi, 6(2).

Bpk.go.id. 2013. Pentingnya Efektivitas Penerapan Sistem Pengendalian Intern dan Pengelolaan Risiko Manajemen di Lingkungan BUMN. http://www. Bpk.go.id, diakses pada tanggal 13 November 2019

Bpk.go.id. 2017. Temuan BPK RI: Ternyata PT. Waskita Karya 'Menjual Pekerjaan' Pembangunan Landscape dan Infrastruktur. https://bandaaceh.bpk.go.id di akses pada April 2020

Catalya, P., \& Hadiprajitno, P. B. (2014). Analisis Dampak Implementasi Sistem Enterprise Resource Planning (ERP) terhadap Efektivitas Pengendalian Internal BUMN dalam Pelaporan Keuangan Di Indonesia (Doctoral dissertation, Fakultas Ekonomika dan Bisnis).

Coso.org. Internal Control -Intergrated Framework (2013)

https://www.coso.org/Pages/default.aspx di akses pada tanggal 30 April 2020

Garside, Annisa Kesy. (2004). Faktor-Faktor Kesuksesan Implementasi Enterprise Resource Planning (ERP) di PT. Semen Gresik.
Herawati, T. (2014). Pengaruh Sistem Pengendalian Intern Terhadap Kualitas Laporan Keuangan (Survei Pada Organisasi Perangkat Daerah Pemda Cianjur). STAR-Study \& Accounting Research, 11(1), 1-14.

Harahap, Seprida. dkk. (2015). Sistem Informasi Akuntansi. Penerbit Cita Pustaka Media: Band

Indrayani, I., \& Maulidahniar, M. (2017). Pengaruh Penerapan Sistem Informasi Akuntansi Terhadap Kualitas Output Sistem Informasi Akuntansi dan Sistem Pengendalian Internal Pada Perusahaan BUMN Pengguna Sistem Enterprise Resource Planning (ERP) di Kota Lhokseumawe. Jurnal Telaah dan Riset Akuntansi, 10(2), 119-138.

Kompas.com 2018. KPK Ingatkan BUMN Jauhi Modus Korupsi Anggaran Proyek Konstruksi. https://nasional.kompas.com, diakses pada tanggal 17 Januari 2020

Poernomo, Y. H. (2011). E-Business: Enterprise Resource Planning (ERP).

Romney. B. M. dan P. J. Steinbart, (2015). Sistem Informasi Akuntansi, (Terjemahan Kikin Sakinah dan Novita Puspasari). Edisi 13. Jakarta: Salemba Empat.

Susanto, Azhar. (2014). Sistem Informasi Akuntansi. Bandung: Lingga Jaya.

Syaifullah, M. A. (2010). Implementasi Data Mining Algoritma Apriori pada Sistem Penjualan. Yogyakarta: STMIK AMIKOM.

Wakhyudi.W. 2018. Soft Controls Aspek Humanisme Dalam Sistem Pengendalian Internal.Yogyakarta: Diandra Kreatif

Waskita.co.id. 2012. Annual Report 2012. http://www. waskita.co.id, diakses pada tanggal 13 November 201 